\title{
Effects of obesity on serum levels of SARS-CoV-2-specific antibodies in COVID-19 patients
}

\author{
Daniela Frasca ${ }^{1,2, \#, ~ L i s a ~ R e i d y ~}{ }^{3, \#}$, Carolyn Cray ${ }^{3}$, Alain Diaz ${ }^{1}$, Maria Romero, \\ Kristin Kahl ${ }^{3}$, Bonnie B. Blomberg ${ }^{1,2}$,
}

${ }^{1}$ Department of Microbiology and Immunology, ${ }^{2}$ Sylvester Comprehensive Cancer Center, ${ }^{3}$ Department of Pathology \& Laboratory Medicine, University of Miami Miller School of Medicine, Miami, FL

\#DF and LR contributed equally to this work.

\begin{abstract}
SARS-CoV-2 (Severe Acute Respiratory Syndrome Corona Virus-2), cause of COVID-19 (Coronavirus Disease of 2019), represents a significant risk to people living with pre-existing conditions associated with exacerbated inflammatory responses and consequent dysfunctional immunity. In this paper, we have evaluated the effects of obesity, a condition associated with chronic systemic inflammation, on the secretion of SARS-CoV-2-specific IgG antibodies in the blood of COVID-19 patients. Results have shown that SARS-CoV-2 IgG antibodies are negatively associated with Body Mass Index (BMI) in COVID-19 obese patients, as expected based on the known effects of obesity on humoral immunity. Antibodies in COVID-19 obese patients are also negatively associated with serum levels of pro-inflammatory and metabolic markers of inflammaging and pulmonary inflammation, such as SAA (serum amyloid A protein), CRP (C-reactive protein) and ferritin, but positively associated with NEFA (nonesterified fatty acids). These results altogether could help to identify an inflammatory signature with strong predictive value for immune dysfunction that could be targeted to improve humoral immunity in individuals with obesity as well as with other chronic inflammatory conditions.
\end{abstract}

Keywords: Obesity, inflammation, antibody responses

\section{Correspondence:}

Daniela Frasca, PhD

University of Miami Miller School of Medicine

Department of Microbiology and Immunology

RMSB 3146A

1600 NW $10^{\text {th }}$ Ave

Miami, FL 33136

e-mail: dfrasca@med.miami.edu (DF) 
medRxiv preprint doi: https://doi.org/10.1101/2020.12.18.20248483; this version posted December 20, 2020. The copyright holder for this preprint (which was not certified by peer review) is the author/funder, who has granted medRxiv a license to display the preprint in perpetuity. All rights reserved. No reuse allowed without permission.

\section{Introduction}

SARS-CoV-2 (Severe Acute Respiratory Syndrome Corona Virus-2), the cause of COVID-19 (Coronavirus Disease of 2019), has been efficiently spreading from human-to-human since the last months of 2019 and has been responsible for mild-to-severe respiratory tract infections. Our knowledge of human immune responses to SARS-CoV-2 infection is limited, and the host factors responsible for disease progression and symptom severity are largely unknown. Recently published data have indicated that chronic low-grade systemic inflammation, inflammaging [1], is the major cause of the cellular and molecular changes induced by SARS-CoV-2 and is responsible for the highest mortality rates [2]. Inflammaging has been shown to induce chronic immune activation (IA) associated with impairment of immune cell function, as reviewed in [3].

Viral clearance and resolution of SARS-CoV-2 infection requires a complex immune response initiated by resident epithelial cells and innate immune cells, followed by adaptive immune cells that effectively cooperate to eliminate the virus. B cells contribute to viral clearance by producing virusspecific antibodies that can neutralize the virus, thus preventing the spread of infectious virions, controlling virus dissemination, and reducing tissue damage. Previously published data have demonstrated strong neutralizing antibody responses generated against the Spike glycoprotein of the SARS-CoV of the 2002-2003 pandemic protected infected hosts from severe disease [4]. Moreover, it has been postulated that during the current pandemic, the production of antibodies to SARS-CoV-2 is critical to limit disease progression and neutralizing antibodies present in plasma from convalescent COVID-19 patients have been shown to induce fast recovery of critically ill patients [5-7].

Obesity, like viral infections, induces persistent local and systemic inflammation and chronic IA, contributing to functional impairment of immune cells, and decreased immunity. Obesity and associated inflammation lead to several debilitating chronic diseases such as type-2 diabetes, cancer, atherosclerosis, and inflammatory bowel disease [8-15]. Therefore, obesity represents an additional risk factor for COVID-19 patients. Also, the prevalence of disease, as well as the occurrence of complications in obese individuals, are increased as compared to lean controls. Indeed, a strong association has been shown between obesity, obesity-associated comorbidities and severe outcomes of COVID-19 [16]. Retrospective analyses of adult COVID-19 symptomatic patients have demonstrated that individuals with Body Mass Index (BMI) >30 were more likely to be admitted to acute and critical care compared to individuals with a $\mathrm{BMI}<30$ [17]. Previously, it has been demonstrated that obese patients respond poorly to infections [18-20], vaccination [21-23], and therapies [24]. The obesity-associated dysregulation of the immune system may also extend the duration and heighten the magnitude of the metabolic stress. It is well known that the obese adipose tissue (AT) is heavily infiltrated with immune cells $[25,26]$ which fuel local inflammation and exacerbate inflammaging. AT in the thorax and abdominal areas induce secretion of additional pro-inflammatory mediators that can further compromise lung function $[27,28]$. The infiltrating immune cells, once activated following SARS-CoV-2 infection, contribute to the release of 
medRxiv preprint doi: https://doi.org/10.1101/2020.12.18.20248483; this version posted December 20, 2020. The copyright holder for this preprint (which was not certified by peer review) is the author/funder, who has granted medRxiv a license to display the preprint in perpetuity. All rights reserved. No reuse allowed without permission.

inflammatory mediators. Another significant health problem is that the AT may be a viral reservoir, playing a crucial role in maintaining local and systemic inflammation, persistent IA, and immune dysfunction [29].

In this study, we have measured serum levels of SARS-CoV-2 Spike-specific IgG antibodies in lean and obese COVID-19 patients as well as in uninfected controls, using an ELISA test developed and standardized in our laboratory. Results show that higher BMI is associated with a higher infection rate with SARS-CoV-2, measured by serum detection of viral RNA and antibodies. Spike-specific lgG antibodies in obese individuals are negatively associated with BMI and with serum levels of proinflammatory and metabolic markers of inflammaging and pulmonary inflammation. Results obtained could help to design an inflammatory signature with a strong predictive value for immune dysfunction that can be targeted to improve humoral immunity in obese infected individuals.

\section{Results}

\section{Evaluation of Spike-specific IgG antibodies in the sera of study participants using an ELISA standardized in our laboratory}

The test group consisted of 52 individuals who were negative, and 72 individuals tested positive for SARS-CoV-2 RNA detection by reverse transcriptase-polymerase chain reaction (RT-PCR) of nasopharyngeal swab samples and serum antibody-positive by lateral flow immunoassay (LFIA) using the lateral flow device (LFD). Age, gender, BMI, routine clinical laboratory measures, and chronic conditions and diseases of the recruited participants are shown in Table 1. Despite several initial reports indicating that COVID-19 patients were characterized by significant lymphocytopenia [30], this cohort had normal numbers of total WBC, neutrophils, and lymphocytes, as also recently shown by other groups [31-33].

In addition to previously measured RT-PCR and LFD results, we also measured IgG antibodies specific for the SARS-CoV-2 (2019-nCoV) S1+S2 (Spike) recombinant protein, using an ELISA developed and standardized in our laboratory. This ELISA confirmed the results previously obtained with RT-PCR and LFD as all the individuals tested negative or positive by RT-PCR and LFD were also negative or positive in our Spike-specific ELISA, respectively. Results in Table 1 show significantly higher levels of Spike-specific IgG antibodies in positive versus negative individuals in our assay.

\section{BMI is higher in SARS-CoV-2 positive versus negative individuals and is associated with severe respiratory symptoms}

Next, we examined the BMI of positive and negative individuals. Results in Fig. 1A show that BMI was higher in positive versus negative individuals (27.7 versus 23.5 , respectively), suggesting a higher frequency of infected patients in obese versus lean individuals. In the group of positives, higher BMI was 
medRxiv preprint doi: https://doi.org/10.1101/2020.12.18.20248483; this version posted December 20, 2020. The copyright holder for this preprint (which was not certified by peer review) is the author/funder, who has granted medRxiv a license to display the preprint in perpetuity. All rights reserved. No reuse allowed without permission.

also associated with severe respiratory symptoms (29.1 versus 24.6 , respectively), as evaluated at the time of hospital admission (Fig. 1B). Severe respiratory symptoms included high fever, cough, shortness of breath, hypoxia, as recorded at the time of hospital admission.

\section{SAA, CRP and ferritin, markers of COVID-19, are higher in positive versus negative individuals and are associated with severe respiratory symptoms}

We measured pro-inflammatory and metabolic markers associated with inflammation in serum samples from positive and negative individuals. We measured SAA (serum amyloid A protein) [34, 35], CRP (C-reactive protein) [36-39] and ferritin [38, 40, 41]. These proteins are markers of pathogen-driven pulmonary inflammation, embolism, and disseminated intravascular coagulation, all characteristics of COVID-19, and therefore predictors of adverse health outcomes. Results in Fig. 2, top show significantly higher levels of these markers in the serum of positive versus negative individuals. In the group of positives, SAA and CRP values were also higher in patients with severe respiratory symptoms than those without symptoms, whereas ferritin showed a trend borderline of significance $(p=0.06)($ Fig. 2 , bottom).

Conversely, and very interestingly, serum levels of NEFA (nonesterified fatty acids) were found lower in positive versus negative individuals and lower in patients with severe respiratory symptoms as compared to those with no symptoms (Fig. 3). These results could be explained by the recently published findings that the receptor binding domain of the Spike protein is physically and tightly bound to an essential fatty acid, the linoleic acid, leading to a locked Spike conformation and reduced ACE2 interaction, at least in vitro [42].

\section{SAA, CRP, and ferritin are positively associated with BMI and negatively associated with Spike- specific $\lg G$}

When we performed correlation analyses between SAA, CRP, ferritin, and NEFA with BMI in positive individuals, we found, as expected, positive associations with SAA, CRP and ferritin, and negative associations with NEFA (Fig. 4). Correlations between serum pro-inflammatory and metabolic markers in the positive individuals are shown in Table 2. Moreover, Spike-specific lgG levels were negatively associated with BMI, SAA, and CRP (Fig. 5, top), and positively associated with NEFA (Fig. 5 , bottom).

\section{Discussion}

To our knowledge, this is the first study of immunological and inflammatory profiles of COVID-19 obese patients. Although this is a rapidly evolving research field, and it has already been shown that individuals with a confirmed PCR diagnosis of infection develop antibodies against the Spike protein [43], how obesity may affect the secretion of SARS-CoV-2-specific IgG is poorly elucidated. Results herein 
medRxiv preprint doi: https://doi.org/10.1101/2020.12.18.20248483; this version posted December 20, 2020. The copyright holder for this preprint (which was not certified by peer review) is the author/funder, who has granted medRxiv a license to display the preprint in perpetuity. All rights reserved. No reuse allowed without permission.

show that serum levels of SARS-CoV-2 IgG antibodies are negatively associated with BMI in COVID-19 patients. This result is consistent with the knowledge that obesity is an inflammatory condition associated with inflammaging [1] and metaflammation [44] both of which are negatively associated with a functional immune system [45]. Another result from the present study is the negative association of SARS-CoV-2 IgG antibodies with markers of pulmonary inflammation (SAA, CRP, ferritin) in our cohort of COVID-19 patients. These are major inflammatory mediators and markers of inflammatory lung injury in patients with catastrophic acute respiratory distress syndrome, which is a primary consequence of COVID-19. SAA, CRP and ferritin are known to induce a cascade of pro-inflammatory events leading to the secretion of additional markers of inflammation that contribute to the exacerbation of local and systemic inflammation resulting in dysfunctional B cells. In particular, SAA has been shown to induce secretion of several pro-inflammatory mediators by macrophages, such as IL-1 $\beta$, TNF- $\alpha$, IL-1RA, IL-8 [46, 47], and IL-33 [48], through activation of NF-kB and IRF7. Similar to SAA, CRP also induces secretion of proinflammatory cytokines (IL-6, IL-1 $\beta$, TNF- $\alpha$ ) [49] and chemokines (CCL2, CCL3, CCL4) [50] by monocytes and macrophages, whereas ferritin induces IL-1 $\beta$ and IL-12p70 in macrophages [51]. No direct effects of SAA, CRP and ferritin on B cells have been reported.

Our previously published work has shown that obesity decreases the serum antibody response to the influenza vaccine in young and elderly individuals [21] and increases the secretion of autoimmune antibodies $[25,52,53]$. We have shown that the serum concentration of leptin, the hormone secreted by the AT [54], correlates with the amount of body fat and BMI [55]. This may be at least one molecular mechanism involved in the reduced B cell function in individuals with obesity, as it induces the secretion of pro-inflammatory cytokines (IL-6/TNF- $\alpha$ ) in human peripheral blood B cells through activation of JAK2/STAT3 and p38MAPK/ERK1/2 signaling pathways $[56,57]$. Leptin also induces intrinsic B cell inflammation as measured by mRNA expression of several markers associated with immunosenescence [58]. Importantly, the expression of these markers in B cells before in vivo/in vitro stimulation negatively correlates with the same B cells' response after stimulation [59].

We have previously shown that obesity also increases blood frequencies of the subset of double negative (DN) B cells (CD19+CD27-IgD-) [21, 53] which represents the most inflammatory $B$ cell subset. Frequencies of DN B cells also increase in the blood of individuals with inflammatory conditions and diseases. These include aging [60-62], autoimmune diseases such as Systemic Lupus Erythematosus [63-65], Rheumatoid Arthritis [66], Sjogren's disease [67], Multiple Sclerosis [68], Alzheimer's disease [69], and pemphigus [70]. An increase of DN B cells have also been reported in the blood of COVID-19 patients and associated with anti-viral antibody responses and poor clinical outcomes, as recently shown [71]. DN B cells secrete pro-inflammatory mediators that contribute to dysfunctional humoral responses and pathogenic autoantibodies that, instead of targeting disease-causing viruses, target infected individuals' tissues. Anti-phospholipids, anti-type-I interferons, anti-nuclear antibodies and Rheumatoid Factor have been found in a large percentage of COVID-19 patients and linked to severe disease as 
medRxiv preprint doi: https://doi.org/10.1101/2020.12.18.20248483; this version posted December 20, 2020. The copyright holder for this preprint (which was not certified by peer review) is the author/funder, who has granted medRxiv a license to display the preprint in perpetuity. All rights reserved. No reuse allowed without permission.

they may inactivate critical components of the anti-viral response [72]. It is also likely, and important to demonstrate, that the neutralizing antibodies in COVID-19 patients may carry autoimmune specificity, as recently shown for broadly neutralizing antibodies against conserved domains in the influenza hemagglutinin with autoreactivity against tissue antigens previously not identified as autoantigens [73]. Overall, these findings support that the SARS-CoV-2 infection, similar to influenza, may induce selftolerance breakdown to a variety of autoantigens with self-tolerance breakdown already occurring in obese individuals. It is also likely that tissue failure following dissemination of the virus through the blood can induce cell death and release of intracellular antigens not known as autoantigens, in addition to those already released in the AT for mechanisms like hypoxia and consequent cell death, as we have previously demonstrated [25]. The quality of the antibody response in COVID-19 patients with obesity is extremely relevant for future vaccination campaigns to prevent SARS-CoV-2 infection and COVID-19associated complications in this population that is likely to be among the first to benefit from vaccination.

\section{Limitations of this study}

There are at least two limitations in our study. First, the number of individuals recruited is limited. We are planning to expand this cohort in the future and with additional markers. Second, this study, although straightforward only shows associations and not mechanisms for the associations. Our future studies will address possibilities after in depth approaches.

\section{Materials and methods}

\section{Enrolled participants}

Experiments were performed using serum samples isolated from individuals tested negative or positive for SARS-CoV-2 RNA by RT-PCR of nasopharyngeal swab samples and by LFIA using the Healgen LFD with specificity for the SARS-CoV-2 Spike antigen. In total, 52 negative and 72 positive serum samples were collected from both inpatient and outpatient settings and frozen until testing was performed. No additional samples were collected from patients, and samples used in this study were only taken for routine clinical care purposes. Samples were de-identified before use in this study. The demographics, BMI, clinical test results, and clinical characteristics of the participants, as well as their SARS-CoV-2-specific IgG ELISA results, are shown in Table 1. This research was approved and reviewed by the Institutional Review Board (IRB, protocols \#20200504) at the University of Miami, which reviews all human research conducted under the auspices of the University of Miami.

Both SARS-CoV-2 RT-PCR and serology tests were performed at the clinical laboratories of the Department of Pathology \& Laboratory Medicine. SARS-CoV-2 RT-PCR was performed at the University of Miami Hospital using either the Diasorin or the BDMax assay and reagents. Depending on submission type (symptomatic or asymptomatic) the sample was assigned and tested per manufacturer guidelines. 
medRxiv preprint doi: https://doi.org/10.1101/2020.12.18.20248483; this version posted December 20, 2020. The copyright holder for this preprint (which was not certified by peer review) is the author/funder, who has granted medRxiv a license to display the preprint in perpetuity. All rights reserved. No reuse allowed without permission.

The Healgen LFD serology test was performed according to the manufacturer guidelines. To each cassette $5 \mu \mathrm{L}$ of serum was added, and two drops of the manufacturer provided buffer solution were applied to the cassette immediately after sample was loaded. Results were read 10 min after. The Healgen LFD were single-channel flow devices, with lgG, IgM, and C (control line) annotated on the cassettes. A pink line in either/or both IgG and IgM was recorded. Because the LFD results are not quantitative, only showing the presence or absence of specific $\lg \mathrm{M} / \lg G$ antibodies, we developed a Spike-specific ELISA (see below) to compare anti-Spike values with the other measures.

\section{ELISA to measure Spike-specific IgG antibodies}

Serum IgG antibodies against SARS-CoV-2 Spike protein were measured by an ELISA developed and standardized in our laboratory. Briefly, 96-well microplates (Immulon 4HBX, Thermo Scientific) were coated with recombinant NCP-CoV (2019-nCoV) Spike protein (S1+S2 ECD) from Sino Biological (\#40589-V08B1) at $2 \mu \mathrm{g} / \mathrm{mL}$ for $1 \mathrm{hr}$ at room temperature. Plates were then washed with Tween-20 0.05\% in PBS (PBST) and blocked with assay buffer (1\% BSA in PBS) for $1 \mathrm{hr}$ at $37^{\circ} \mathrm{C}$. All subsequent steps after blocking were performed by a DYNEX DS2® Automated ELISA system (DYNEX Technologies). Serum samples diluted 1:50,000 in assay buffer were added in duplicate and plates were incubated for $2 \mathrm{hrs}$. Plates were washed with PBST and $100 \mu \mathrm{L}$ per well of a peroxidase-conjugated goat anti-human IgG (Jackson ImmunoResearch \#109-036-098), diluted 1:10,000 in assay buffer, were added. After $1 \mathrm{hr}$ incubation, plates were washed and a stabilized 3,3',5,5'-Tetramethylbenzidine (TMB) substrate (Sigma) was added to the wells. The enzymatic reaction was stopped after 20 min with a Stop solution (1 M sulfuric acid), and absorbance at $450 \mathrm{~nm}$ was read by the DYNEX DS2 instrument.

\section{ELISA to measure serum pro-inflammatory and metabolic markers}

Serum levels of SAA, CRP, ferritin, and NEFA were measured using the following commercially available kits. SAA: Life Diagnostic \#SAA-20. CRP: R\&D \# DCRP00. Ferritin: Thermo Scientific \#EHFTL. NEFA: abcam \#ab65341.

\section{Statistical analyses}

To examine differences between groups, unpaired Student's t tests (two-tailed) were used. To examine relationships between variables, bivariate Pearson's correlation analyses were performed, using GraphPad Prism version 8 software, which was used to construct all graphs. 


\section{Acknowledgements}

This study was supported by NIH awards AG32576 (DF/BBB), AG059719 (DF), and by the University of Miami Department of Pathology \& Laboratory Medicine.

\section{Author Contributions}

Conceptualization: DF, BBB, LR, CC

Data curation: DF, AD, MR, BBB, LR, CC, KK

Formal analysis: DF, BBB, $A D, M R$

Funding acquisition: DF, BBB, CC

Investigation: DF, BBB, LR, CC

Methodology: AD, MR, KK

Project administration: DF, BBB, LR, CC

Resources: DF, BBB, LR, CC

Supervision: DF, BBB, LR, CC

Validation: AD, MR, KK

Writing - original draft: DF

Writing - review \& editing: DF, AD, MR, BBB, LR, CC, KK

Conflict of Interest Statement: The authors declare no conflict of interest. 
medRxiv preprint doi: https://doi.org/10.1101/2020.12.18.20248483; this version posted December 20, 2020. The copyright holder for this preprint (which was not certified by peer review) is the author/funder, who has granted medRxiv a license to display the preprint in perpetuity. All rights reserved. No reuse allowed without permission.

\section{References}

1. Franceschi C, Bonafe M, Valensin S, Olivieri F, De Luca M, Ottaviani E, et al. Inflamm-aging. An evolutionary perspective on immunosenescence. Ann N Y Acad Sci. 2000;908:244-54. PubMed PMID: 10911963.

2. Mueller AL, McNamara MS, Sinclair DA. Why does COVID-19 disproportionately affect older people? Aging (Albany NY). 2020;12(10):9959-81. doi: 10.18632/aging.103344. PubMed PMID: 32470948; PubMed Central PMCID: PMCPMC7288963.

3. Frasca D, Diaz A, Romero M, Garcia D, Blomberg BB. B Cell Immunosenescence. Annu Rev Cell Dev Biol. 2020;36:551-74. doi: 10.1146/annurev-cellbio-011620-034148. PubMed PMID: 33021823.

4. Newton $\mathrm{AH}$, Cardani A, Braciale TJ. The host immune response in respiratory virus infection: balancing virus clearance and immunopathology. Semin Immunopathol. 2016;38(4):471-82. doi: 10.1007/s00281-016-0558-0. PubMed PMID: 26965109; PubMed Central PMCID: PMCPMC4896975.

5. Casadevall A, Pirofski LA. The convalescent sera option for containing COVID-19. J Clin Invest. 2020;130(4):1545-8. doi: 10.1172/JCI138003. PubMed PMID: 32167489; PubMed Central PMCID: PMCPMC7108922.

6. Duan K, Liu B, Li C, Zhang H, Yu T, Qu J, et al. Effectiveness of convalescent plasma therapy in severe COVID-19 patients. Proc Natl Acad Sci U S A. 2020;117(17):9490-6. doi:

10.1073/pnas.2004168117. PubMed PMID: 32253318; PubMed Central PMCID: PMCPMC7196837.

7. Langhi DM, Santis GC, Bordin JO. COVID-19 convalescent plasma transfusion. Hematol Transfus Cell Ther. 2020;42(2):113-5. doi: 10.1016/j.htct.2020.04.003. PubMed PMID: 32313872; PubMed Central PMCID: PMCPMC7164882.

8. Apovian CM, Gokce N. Obesity and cardiovascular disease. Circulation. 2012;125(9):1178-82. doi: 10.1161/CIRCULATIONAHA.111.022541. PubMed PMID: 22392865; PubMed Central PMCID: PMCPMC3693443.

9. Casas R, Sacanella E, Estruch R. The immune protective effect of the Mediterranean diet against chronic low-grade inflammatory diseases. Endocr Metab Immune Disord Drug Targets. 2014;14(4):24554. doi: 10.2174/1871530314666140922153350. PubMed PMID: 25244229; PubMed Central PMCID: PMCPMC4443792.

10. Hass DJ, Brensinger CM, Lewis JD, Lichtenstein GR. The impact of increased body mass index on the clinical course of Crohn's disease. Clin Gastroenterol Hepatol. 2006;4(4):482-8. doi: 10.1016/j.cgh.2005.12.015. PubMed PMID: 16616354.

11. Hotamisligil GS. Inflammation and metabolic disorders. Nature. 2006;444(7121):860-7. doi: 10.1038/nature05485. PubMed PMID: 17167474.

12. Johnson AM, Olefsky JM. The origins and drivers of insulin resistance. Cell. 2013;152(4):673-84. doi: 10.1016/j.cell.2013.01.041. PubMed PMID: 23415219.

13. Renehan AG, Tyson M, Egger M, Heller RF, Zwahlen M. Body-mass index and incidence of cancer: a systematic review and meta-analysis of prospective observational studies. Lancet. 2008;371(9612):569-78. doi: 10.1016/S0140-6736(08)60269-X. PubMed PMID: 18280327. 
medRxiv preprint doi: https://doi.org/10.1101/2020.12.18.20248483; this version posted December 20, 2020. The copyright holder for this preprint (which was not certified by peer review) is the author/funder, who has granted medRxiv a license to display the preprint in perpetuity. All rights reserved. No reuse allowed without permission.

14. Setty AR, Curhan G, Choi HK. Obesity, waist circumference, weight change, and the risk of psoriasis in women: Nurses' Health Study II. Arch Intern Med. 2007;167(15):1670-5. doi:

10.1001/archinte.167.15.1670. PubMed PMID: 17698691.

15. Shoelson SE, Lee J, Goldfine AB. Inflammation and insulin resistance. J Clin Invest. 2006;116(7):1793-801. doi: 10.1172/JCI29069. PubMed PMID: 16823477; PubMed Central PMCID: PMCPMC1483173.

16. Ritter A, Kreis NN, Louwen F, Yuan J. Obesity and COVID-19: Molecular Mechanisms Linking Both Pandemics. Int J Mol Sci. 2020;21(16). doi: 10.3390/ijms21165793. PubMed PMID: 32806722; PubMed Central PMCID: PMCPMC7460849.

17. Lighter J, Phillips M, Hochman S, Sterling S, Johnson D, Francois F, et al. Obesity in Patients Younger Than 60 Years Is a Risk Factor for COVID-19 Hospital Admission. Clin Infect Dis. 2020;71(15):896-7. doi: 10.1093/cid/ciaa415. PubMed PMID: 32271368; PubMed Central PMCID: PMCPMC7184372.

18. Falagas ME, Kompoti M. Obesity and infection. Lancet Infect Dis. 2006;6(7):438-46. doi: 10.1016/S1473-3099(06)70523-0. PubMed PMID: 16790384.

19. Karlsson EA, Beck MA. The burden of obesity on infectious disease. Exp Biol Med (Maywood). 2010;235(12):1412-24. doi: 10.1258/ebm.2010.010227. PubMed PMID: 21127339.

20. O'Shea D, Corrigan M, Dunne MR, Jackson R, Woods C, Gaoatswe G, et al. Changes in human dendritic cell number and function in severe obesity may contribute to increased susceptibility to viral infection. Int J Obes (Lond). 2013;37(11):1510-3. doi: 10.1038/ijo.2013.16. PubMed PMID: 23439322.

21. Frasca D, Ferracci F, Diaz A, Romero M, Lechner S, Blomberg BB. Obesity decreases B cell responses in young and elderly individuals. Obesity (Silver Spring). 2016;24(3):615-25. doi: 10.1002/oby.21383. PubMed PMID: 26857091; PubMed Central PMCID: PMCPMC4769695.

22. Ovsyannikova IG, White SJ, Larrabee BR, Grill DE, Jacobson RM, Poland GA. Leptin and leptinrelated gene polymorphisms, obesity, and influenza $\mathrm{A} / \mathrm{H} 1 \mathrm{~N} 1$ vaccine-induced immune responses in older individuals. Vaccine. 2014;32(7):881-7. doi: 10.1016/j.vaccine.2013.12.009. PubMed PMID: 24360890; PubMed Central PMCID: PMCPMC3922536.

23. Sheridan PA, Paich HA, Handy J, Karlsson EA, Hudgens MG, Sammon AB, et al. Obesity is associated with impaired immune response to influenza vaccination in humans. Int $\mathrm{J}$ Obes (Lond). 2012;36(8):1072-7. doi: 10.1038/ijo.2011.208. PubMed PMID: 22024641; PubMed Central PMCID: PMCPMC3270113.

24. George MD, Baker JF. The Obesity Epidemic and Consequences for Rheumatoid Arthritis Care. Curr Rheumatol Rep. 2016;18(1):6. doi: 10.1007/s11926-015-0550-z. PubMed PMID: 26739963; PubMed Central PMCID: PMCPMC4809046.

25. Frasca D, Diaz A, Romero M, Thaller S, Blomberg BB. Secretion of autoimmune antibodies in the human subcutaneous adipose tissue. PLoS One. 2018;13(5):e0197472. doi: 10.1371/journal.pone.0197472. PubMed PMID: 29768501; PubMed Central PMCID: PMCPMC5955545.

26. Grant RW, Dixit VD. Adipose tissue as an immunological organ. Obesity (Silver Spring). 2015;23(3):512-8. doi: 10.1002/oby.21003. PubMed PMID: 25612251; PubMed Central PMCID: PMCPMC4340740. 
medRxiv preprint doi: https://doi.org/10.1101/2020.12.18.20248483; this version posted December 20, 2020. The copyright holder for this preprint (which was not certified by peer review) is the author/funder, who has granted medRxiv a license to display the preprint in perpetuity. All rights reserved. No reuse allowed without permission.

27. Franssen FM, O'Donnell DE, Goossens GH, Blaak EE, Schols AM. Obesity and the lung: 5 . Obesity and COPD. Thorax. 2008;63(12):1110-7. doi: 10.1136/thx.2007.086827. PubMed PMID: 19020276.

28. Murugan AT, Sharma G. Obesity and respiratory diseases. Chron Respir Dis. 2008;5(4):233-42. doi: 10.1177/1479972308096978. PubMed PMID: 19029235.

29. Kruglikov IL, Scherer PE. The role of adipocytes and adipocyte-like cells in the severity of COVID-19 infections. Obesity (Silver Spring). 2020; https://doi.org/10.1002/oby.22856. doi: 10.1002/oby.22856. PubMed PMID: 32339391.

30. Tan L, Wang Q, Zhang D, Ding J, Huang Q, Tang YQ, et al. Lymphopenia predicts disease severity of COVID-19: a descriptive and predictive study. Signal Transduct Target Ther. 2020;5(1):33. doi: 10.1038/s41392-020-0148-4. PubMed PMID: 32296069; PubMed Central PMCID:

PMCPMC7100419.

31. Arunachalam PS, Wimmers F, Mok CKP, Perera R, Scott M, Hagan T, et al. Systems biological assessment of immunity to mild versus severe COVID-19 infection in humans. Science. 2020;369(6508):1210-20. doi: 10.1126/science.abc6261. PubMed PMID: 32788292.

32. Mathew D, Giles JR, Baxter AE, Oldridge DA, Greenplate AR, Wu JE, et al. Deep immune profiling of COVID-19 patients reveals distinct immunotypes with therapeutic implications. Science. 2020;369(6508). doi: 10.1126/science.abc8511. PubMed PMID: 32669297; PubMed Central PMCID: PMCPMC7402624.

33. Woodruff MC, Ramonell RP, Nguyen DC, Cashman KS, Saini AS, Haddad NS, et al. Extrafollicular B cell responses correlate with neutralizing antibodies and morbidity in COVID-19. Nat Immunol. 2020. doi: 10.1038/s41590-020-00814-z. PubMed PMID: 33028979.

34. Cheng L, Yang JZ, Bai WH, Li ZY, Sun LF, Yan JJ, et al. Prognostic value of serum amyloid A in patients with COVID-19. Infection. 2020;48(5):715-22. doi: 10.1007/s15010-020-01468-7. PubMed PMID: 32734556; PubMed Central PMCID: PMCPMC7391472.

35. Li H, Xiang X, Ren H, Xu L, Zhao L, Chen X, et al. Serum Amyloid A is a biomarker of severe Coronavirus Disease and poor prognosis. J Infect. 2020;80(6):646-55. doi: 10.1016/j.jinf.2020.03.035. PubMed PMID: 32277967; PubMed Central PMCID: PMCPMC7141628.

36. Luo X, Zhou W, Yan X, Guo T, Wang B, Xia H, et al. Prognostic value of C-reactive protein in patients with COVID-19. Clin Infect Dis. 2020. doi: 10.1093/cid/ciaa641. PubMed PMID: 32445579; PubMed Central PMCID: PMCPMC7314209.

37. Manson JJ, Crooks C, Naja M, Ledlie A, Goulden B, Liddle T, et al. COVID-19-associated hyperinflammation and escalation of patient care: a retrospective longitudinal cohort study. Lancet Rheumatol. 2020;2(10):e594-e602. doi: 10.1016/S2665-9913(20)30275-7. PubMed PMID: 32864628; PubMed Central PMCID: PMCPMC7442426.

38. Velavan TP, Meyer CG. Mild versus severe COVID-19: Laboratory markers. Int J Infect Dis. 2020;95:304-7. doi: 10.1016/j.jjid.2020.04.061. PubMed PMID: 32344011; PubMed Central PMCID: PMCPMC7194601.

39. Wang L. C-reactive protein levels in the early stage of COVID-19. Med Mal Infect. 2020;50(4):332-4. doi: 10.1016/j.medmal.2020.03.007. PubMed PMID: 32243911; PubMed Central PMCID: PMCPMC7146693. 
medRxiv preprint doi: https://doi.org/10.1101/2020.12.18.20248483; this version posted December 20, 2020. The copyright holder for this preprint (which was not certified by peer review) is the author/funder, who has granted medRxiv a license to display the preprint in perpetuity. All rights reserved. No reuse allowed without permission.

40. Gomez-Pastora J, Weigand M, Kim J, Wu X, Strayer J, Palmer AF, et al. Hyperferritinemia in critically ill COVID-19 patients - Is ferritin the product of inflammation or a pathogenic mediator? Clin Chim Acta. 2020;509:249-51. doi: 10.1016/j.cca.2020.06.033. PubMed PMID: 32579952; PubMed Central PMCID: PMCPMC7306200.

41. Zhou F, Yu T, Du R, Fan G, Liu Y, Liu Z, et al. Clinical course and risk factors for mortality of adult inpatients with COVID-19 in Wuhan, China: a retrospective cohort study. Lancet. 2020;395(10229):1054-62. doi: 10.1016/S0140-6736(20)30566-3. PubMed PMID: 32171076; PubMed Central PMCID: PMCPMC7270627.

42. Toelzer C, Gupta K, Yadav SKN, Borucu U, Davidson AD, Kavanagh Williamson M, et al. Free fatty acid binding pocket in the locked structure of SARS-CoV-2 spike protein. Science. 2020;370(6517):725-30. doi: 10.1126/science.abd3255. PubMed PMID: 32958580.

43. Seow J, Graham C, Merrick B, Acors S, Pickering S, Steel KJA, et al. Longitudinal observation and decline of neutralizing antibody responses in the three months following SARS-CoV-2 infection in humans. Nat Microbiol. 2020;5(12):1598-607. doi: 10.1038/s41564-020-00813-8. PubMed PMID: 33106674 .

44. Hotamisligil GS. Inflammation, metaflammation and immunometabolic disorders. Nature. 2017;542(7640):177-85. doi: 10.1038/nature21363. PubMed PMID: 28179656.

45. Ahima RS. Connecting obesity, aging and diabetes. Nat Med. 2009;15(9):996-7. doi: 10.1038/nm0909-996. PubMed PMID: 19734871.

46. Furlaneto CJ, Campa A. A novel function of serum amyloid A: a potent stimulus for the release of tumor necrosis factor-alpha, interleukin-1 beta, and interleukin-8 by human blood neutrophil. Biochem Biophys Res Commun. 2000;268(2):405-8. doi: 10.1006/bbrc.2000.2143. PubMed PMID: 10679217.

47. Patel H, Fellowes R, Coade S, Woo P. Human serum amyloid A has cytokine-like properties. Scand J Immunol. 1998;48(4):410-8. doi: 10.1046/j.1365-3083.1998.00394.x. PubMed PMID: 9790312.

48. Sun L, Zhu Z, Cheng N, Yan Q, Ye RD. Serum amyloid A induces interleukin-33 expression through an IRF7-dependent pathway. Eur J Immunol. 2014;44(7):2153-64. doi: 10.1002/eji.201344310. PubMed PMID: 24777946; PubMed Central PMCID: PMCPMC4118754.

49. Ballou SP, Lozanski G. Induction of inflammatory cytokine release from cultured human monocytes by C-reactive protein. Cytokine. 1992;4(5):361-8. doi: 10.1016/1043-4666(92)90079-7. PubMed PMID: 1420997.

50. Montecucco F, Steffens S, Burger F, Pelli G, Monaco C, Mach F. C-reactive protein (CRP) induces chemokine secretion via CD11b/ICAM-1 interaction in human adherent monocytes. J Leukoc Biol. 2008;84(4):1109-19. doi: 10.1189/jlb.0208123. PubMed PMID: 18591415.

51. Ruscitti P, Di Benedetto P, Berardicurti O, Panzera N, Grazia N, Lizzi AR, et al. Pro-inflammatory properties of $\mathrm{H}$-ferritin on human macrophages, ex vivo and in vitro observations. Sci Rep. 2020;10(1):12232. doi: 10.1038/s41598-020-69031-w. PubMed PMID: 32699419; PubMed Central PMCID: PMCPMC7376151.

52. Frasca D, Diaz A, Romero M, Garcia D, Jayram D, Thaller S, et al. Identification and Characterization of Adipose Tissue-Derived Human Antibodies With "Anti-self" Specificity. Front Immunol. 2020;11:392. doi: 10.3389/fimmu.2020.00392. PubMed PMID: 32184790; PubMed Central PMCID: PMCPMC7058997. 
medRxiv preprint doi: https://doi.org/10.1101/2020.12.18.20248483; this version posted December 20, 2020. The copyright holder for this preprint (which was not certified by peer review) is the author/funder, who has granted medRxiv a license to display the preprint in perpetuity. All rights reserved. No reuse allowed without permission.

53. Frasca D, Diaz A, Romero M, Thaller S, Blomberg BB. Metabolic requirements of human proinflammatory B cells in aging and obesity. PLoS One. 2019;14(7):e0219545. doi:

10.1371/journal.pone.0219545. PubMed PMID: 31287846; PubMed Central PMCID: PMCPMC6615614.

54. Zhang Y, Proenca R, Maffei M, Barone M, Leopold L, Friedman JM. Positional cloning of the mouse obese gene and its human homologue. Nature. 1994;372(6505):425-32. doi: 10.1038/372425a0. PubMed PMID: 7984236.

55. La Cava A, Matarese G. The weight of leptin in immunity. Nat Rev Immunol. 2004;4(5):371-9. doi: 10.1038/nri1350. PubMed PMID: 15122202.

56. Agrawal S, Gollapudi S, Su H, Gupta S. Leptin activates human B cells to secrete TNF-alpha, IL6, and IL-10 via JAK2/STAT3 and p38MAPK/ERK1/2 signaling pathway. J Clin Immunol. 2011;31(3):4728. doi: 10.1007/s10875-010-9507-1. PubMed PMID: 21243519; PubMed Central PMCID: PMCPMC3132280.

57. Gupta S, Agrawal S, Gollapudi S. Increased activation and cytokine secretion in B cells stimulated with leptin in aged humans. Immun Ageing. 2013;10(1):3. doi: 10.1186/1742-4933-10-3. PubMed PMID: 23343052; PubMed Central PMCID: PMCPMC3557206.

58. Frasca D, Diaz A, Romero M, Blomberg BB. Leptin induces immunosenescence in human B cells. Cell Immunol. 2020;348:103994. doi: 10.1016/j.cellimm.2019.103994. PubMed PMID: 31831137; PubMed Central PMCID: PMCPMC7002206.

59. Frasca D, Diaz A, Romero M, Landin AM, Blomberg BB. High TNF-alpha levels in resting B cells negatively correlate with their response. Exp Gerontol. 2014;54:116-22. doi: 10.1016/j.exger.2014.01.004. PubMed PMID: 24440385; PubMed Central PMCID: PMC3989457.

60. Colonna-Romano G, Bulati M, Aquino A, Pellicano M, Vitello S, Lio D, et al. A double-negative (IgD-CD27-) B cell population is increased in the peripheral blood of elderly people. Mech Ageing Dev. 2009;130(10):681-90. doi: 10.1016/j.mad.2009.08.003. PubMed PMID: 19698733.

61. Frasca D, Diaz A, Romero M, Blomberg BB. Human peripheral late/exhausted memory B cells express a senescent-associated secretory phenotype and preferentially utilize metabolic signaling pathways. Exp Gerontol. 2017;87(Pt A):113-20. doi: 10.1016/j.exger.2016.12.001. PubMed PMID: 27931848.

62. Nevalainen T, Autio A, Kummola L, Salomaa T, Junttila I, Jylha M, et al. CD27- IgD- B cell memory subset associates with inflammation and frailty in elderly individuals but only in males. Immun Ageing. 2019;16:19. doi: 10.1186/s12979-019-0159-6. PubMed PMID: 31423147; PubMed Central PMCID: PMCPMC6693136.

63. Jenks SA, Cashman KS, Zumaquero E, Marigorta UM, Patel AV, Wang X, et al. Distinct Effector B Cells Induced by Unregulated Toll-like Receptor 7 Contribute to Pathogenic Responses in Systemic Lupus Erythematosus. Immunity. 2018;49(4):725-39 e6. doi: 10.1016/j.immuni.2018.08.015. PubMed PMID: 30314758; PubMed Central PMCID: PMCPMC6217820.

64. Wang S, Wang J, Kumar V, Karnell JL, Naiman B, Gross PS, et al. IL-21 drives expansion and plasma cell differentiation of autoreactive CD11c(hi)T-bet(+) B cells in SLE. Nat Commun. 2018;9(1):1758. doi: 10.1038/s41467-018-03750-7. PubMed PMID: 29717110; PubMed Central PMCID: PMCPMC5931508.

65. Wehr C, Eibel H, Masilamani M, Illges $\mathrm{H}$, Schlesier M, Peter HH, et al. A new CD21low B cell population in the peripheral blood of patients with SLE. Clin Immunol. 2004;113(2):161-71. doi: 10.1016/j.clim.2004.05.010. PubMed PMID: 15451473. 
medRxiv preprint doi: https://doi.org/10.1101/2020.12.18.20248483; this version posted December 20, 2020. The copyright holder for this preprint (which was not certified by peer review) is the author/funder, who has granted medRxiv a license to display the preprint in perpetuity. All rights reserved. No reuse allowed without permission.

66. Adlowitz DG, Barnard J, Biear JN, Cistrone C, Owen T, Wang W, et al. Expansion of Activated Peripheral Blood Memory B Cells in Rheumatoid Arthritis, Impact of B Cell Depletion Therapy, and Biomarkers of Response. PLoS One. 2015;10(6):e0128269. doi: 10.1371/journal.pone.0128269. PubMed PMID: 26047509; PubMed Central PMCID: PMCPMC4457888.

67. Saadoun D, Terrier B, Bannock J, Vazquez T, Massad C, Kang I, et al. Expansion of autoreactive unresponsive CD21-/low B cells in Sjogren's syndrome-associated lymphoproliferation. Arthritis Rheum. 2013;65(4):1085-96. doi: 10.1002/art.37828. PubMed PMID: 23279883; PubMed Central PMCID: PMCPMC4479193.

68. Claes N, Fraussen J, Vanheusden M, Hellings N, Stinissen P, Van Wijmeersch B, et al. AgeAssociated B Cells with Proinflammatory Characteristics Are Expanded in a Proportion of Multiple Sclerosis Patients. J Immunol. 2016;197(12):4576-83. doi: 10.4049/jimmunol.1502448. PubMed PMID: 27837111.

69. Martorana A, Balistreri CR, Bulati M, Buffa S, Azzarello DM, Camarda C, et al. Double negative (CD19+lgG+lgD-CD27-) B lymphocytes: a new insight from telomerase in healthy elderly, in centenarian offspring and in Alzheimer's disease patients. Immunol Lett. 2014;162(1 Pt B):303-9. doi: 10.1016/j.imlet.2014.06.003. PubMed PMID: 24951896.

70. Golinski ML, Demeules M, Derambure C, Riou G, Maho-Vaillant M, Boyer O, et al. CD11c(+) B Cells Are Mainly Memory Cells, Precursors of Antibody Secreting Cells in Healthy Donors. Front Immunol. 2020;11:32. doi: 10.3389/fimmu.2020.00032. PubMed PMID: 32158442; PubMed Central PMCID: PMCPMC7051942.

71. Woodruff MC, Ramonell RP, Nguyen DC, Cashman KS, Saini AS, Haddad NS, et al. Extrafollicular B cell responses correlate with neutralizing antibodies and morbidity in COVID-19. Nat Immunol. 2020;21(12):1506-16. doi: 10.1038/s41590-020-00814-z. PubMed PMID: 33028979.

72. Woodruff M, Ramonell R, Lee E-H, Sanz I. Clinically identifiable autoreactivity is common in severe SARS-CoV-2 Infection. medRxiv. 2020. doi: 10.1101/2020.10.21.2021619201/2020.04.29.20083717. PubMed PMID: 32511635; PubMed Central PMCID: PMCPMC7276991.

73. Khurana S, Hahn M, Klenow L, Golding H. Autoreactivity of Broadly Neutralizing Influenza Human Antibodies to Human Tissues and Human Proteins. Viruses. 2020;12(10). doi: 10.3390/v12101140. PubMed PMID: 33049994; PubMed Central PMCID: PMCPMC7600923. 
medRxiv preprint doi: https://doi.org/10.1101/2020.12.18.20248483; this version posted December 20, 2020. The copyright holder for this preprint (which was not certified by peer review) is the author/funder, who has granted medRxiv a license to display the preprint in perpetuity. All rights reserved. No reuse allowed without permission.

\section{Figure legends}

Figure 1. BMI is higher in positive versus negative individuals and is associated with severe respiratory symptoms. A. BMI in participants tested negative and positive by Spike-specific ELISA. B. BMI in COVID-19 positive patients with $(n=46)$ or without $(n=20)$ severe respiratory symptoms. Severe respiratory symptoms included high fever, cough, shortness of breath, hypoxia, as determined at the time of hospital admission. ${ }^{* *} p<0.01,{ }^{* *} p<0.001$.

Figure 2. SAA, CRP and ferritin, markers of COVID-19, are higher in positive versus negative individuals and are associated with severe respiratory symptoms. Top. SAA, CRP and ferritin were detected in serum samples of participants tested negative and positive. Bottom. SAA, CRP and ferritin in serum samples of COVID-19 positive patients with [n=42 (SAA), $n=38$ (CRP), n=48 (ferritin)] or without [n=10 (SAA), n=10 (CRP), n=16 (ferritin)] severe respiratory symptoms (as defined in Fig. 1). * $p<0.05$, ${ }^{* *} p<0.01,{ }^{* * *} p<0.001$.

Figure 3. NEFA are lower in positive versus negative individuals. Top. NEFA in serum samples of participants tested negative and positive. Bottom. NEFA in serum samples of COVID-19 positive patients with $(n=31)$ or without $(n=7)$ severe respiratory symptoms (as defined in Fig. 1$) .{ }^{* *} p<0.01$, ${ }^{* * *} p<0.001$.

Figure 4. SAA, CRP and ferritin are positively associated, whereas NEFA are negatively associated, with BMI. Correlations of SAA, CRP and ferritin with BMI. Pearson's regression coefficients and $p$ values are indicated at the bottom of each figure.

Figure 5. Spike-specific IgG are negatively associated with SAA and CRP and positively associated with NEFA. Correlations of Spike-specific IgG antibodies with BMI, SAA, CRP, ferritin and NEFA. Pearson's regression coefficients and $p$ values are indicated at the bottom of each figure. 
medRxiv preprint doi: https://doi.org/10.1101/2020.12.18.20248483; this version posted December 20, 2020. The copyright holder for this preprint (which was not certified by peer review) is the author/funder, who has granted medRxiv a license to display the preprint in perpetuity.

All rights reserved. No reuse allowed without permission.

Table 1. Demographics, laboratory and clinical characteristics of enrolled participants

\begin{tabular}{|c|c|c|}
\hline & $\begin{array}{c}\text { Negatives } \\
(n=52)\end{array}$ & $\begin{array}{c}\text { Positives } \\
(n=72)\end{array}$ \\
\hline Age, mean $\pm S E$ & $33 \pm 3$ & $65 \pm 2 * * * *$ \\
\hline $\mathrm{BMI}$, mean \pm SE (range) & $23.5 \pm 1.4(17.4-33.4)$ & $27.7 \pm 2.0(19.4-45.6)$ *** \\
\hline Males & 15 & 40 \\
\hline Females & 37 & 32 \\
\hline Spike-specific lgG (OD) & $0.64 \pm 0.07$ & $1.43 \pm 0.28^{* * * *}$ \\
\hline Total WBC $\left(\times 10^{3} / \mu \mathrm{l}\right)^{\wedge}$ & $7.22 \pm 0.76$ & $8.56 \pm 0.54$ \\
\hline Neutrophils $\left(\times 10^{3} / \mu \mathrm{l}\right)^{\wedge \wedge}$ & $4.85 \pm 0.99$ & $6.16 \pm 0.52$ \\
\hline Lymphocytes $\left(\times 10^{3} / \mu \mathrm{l}\right)^{\wedge \wedge \wedge}$ & $1.49 \pm 0.24$ & $1.36 \pm 0.09$ \\
\hline \multicolumn{3}{|l|}{ Chronic conditions/diseases } \\
\hline Lung disease & 0 & $14^{a}$ \\
\hline Type-2 Diabetes Mellitus & 1 & 23 \\
\hline Coronary Heart disease & 0 & 12 \\
\hline Autoimmune disease & 0 & $7^{b}$ \\
\hline Cancer & $2^{c}$ & $9^{d}$ \\
\hline Infectious disease & 0 & $1^{\mathrm{e}}$ \\
\hline
\end{tabular}

${ }^{* * *} p<0.001,{ }^{* * * *} p<0.0001$

${ }^{\wedge}$ Normal values: $3.8-10.8 \times 10^{3} / \mu l$

^^Normal values: $2.5-8 \times 10^{3} / \mu \mathrm{l}$

$\wedge \wedge \wedge$ Normal values: $1-4.8 \times 10^{3} / \mu \mathrm{l}$

aLung disease patients: COPD (9), Hypersensitivity Lung disease (5)

${ }^{\text {b} A u t o i m m u n e ~ d i s e a s e ~ p a t i e n t s: ~ T y p e-1 ~ D i a b e t e s ~(2), ~ P a r k i n s o n ' s ~(1), ~ A l z h e i m e r ' s / d e m e n t i a ~(3), ~ A d d i s o n ~}$

(1)

${ }^{\mathrm{c}}$ Cancer patients: leukemia (2)

${ }^{d}$ Cancer patients: breast cancer (2), lung cancer (4), sarcoma (1), vulvar cancer (2)

enfectious disease patients: hepatitis (1) 
medRxiv preprint doi: https://doi.org/10.1101/2020.12.18.20248483; this version posted December 20, 2020. The copyright holder for this preprint (which was not certified by peer review) is the author/funder, who has granted medRxiv a license to display the preprint in perpetuity.

All rights reserved. No reuse allowed without permission.

Table 2. Correlations between serum pro-inflammatory and metabolic markers in the positive participants

Correlation Person's $r \quad P$ value

SAA \& ferritin

0.43

0.0029

SAA \& CRP

0.52

0.0005

SAA \& NEFA

$-0.41$

0.02

Ferritin \& CRP

0.05

0.73

Ferritin \& NEFA

$-0.11$

0.05

CRP \& NEFA

$-0.30$

0.06

In bold are indicated the correlations that are significant 

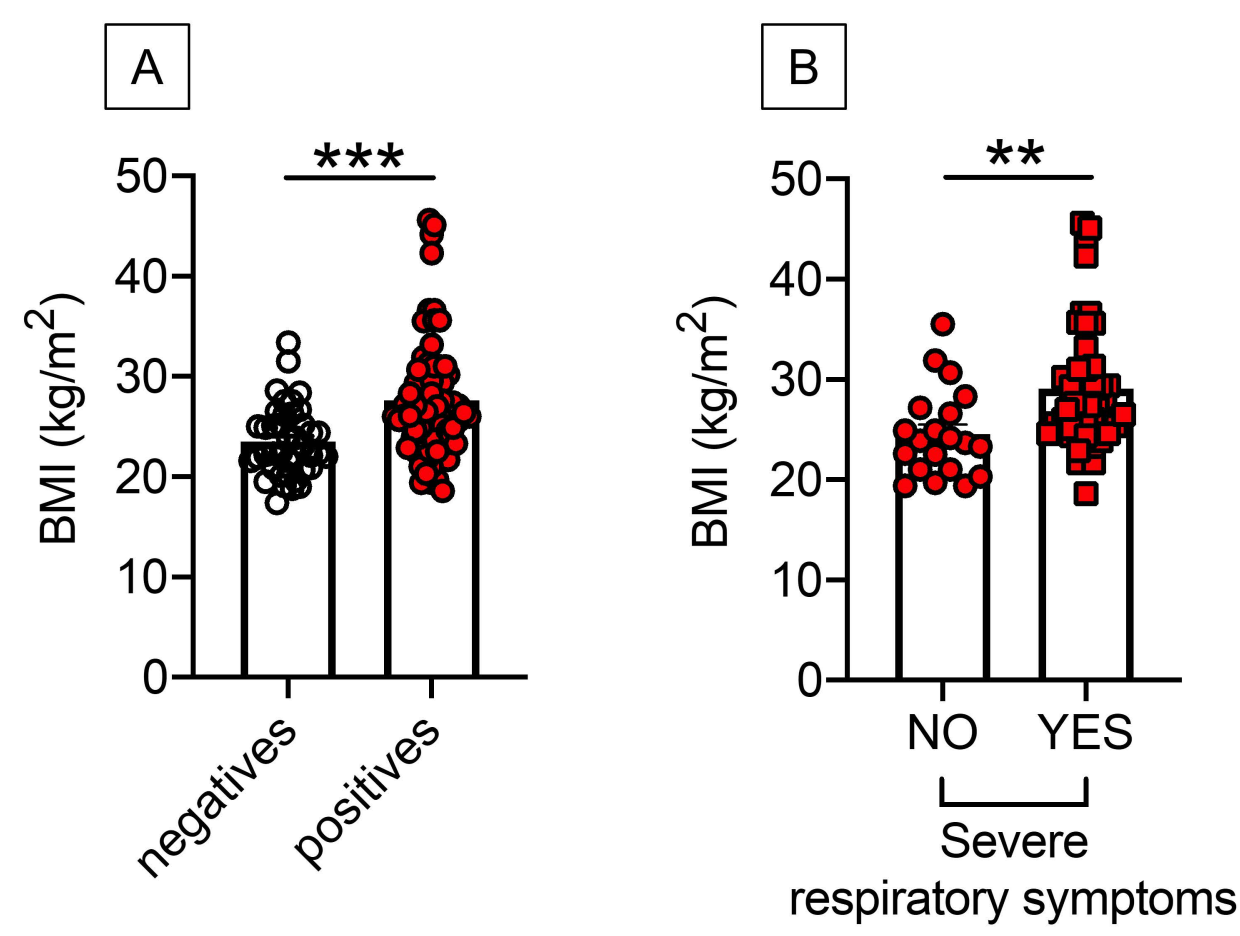

Fig. 1 

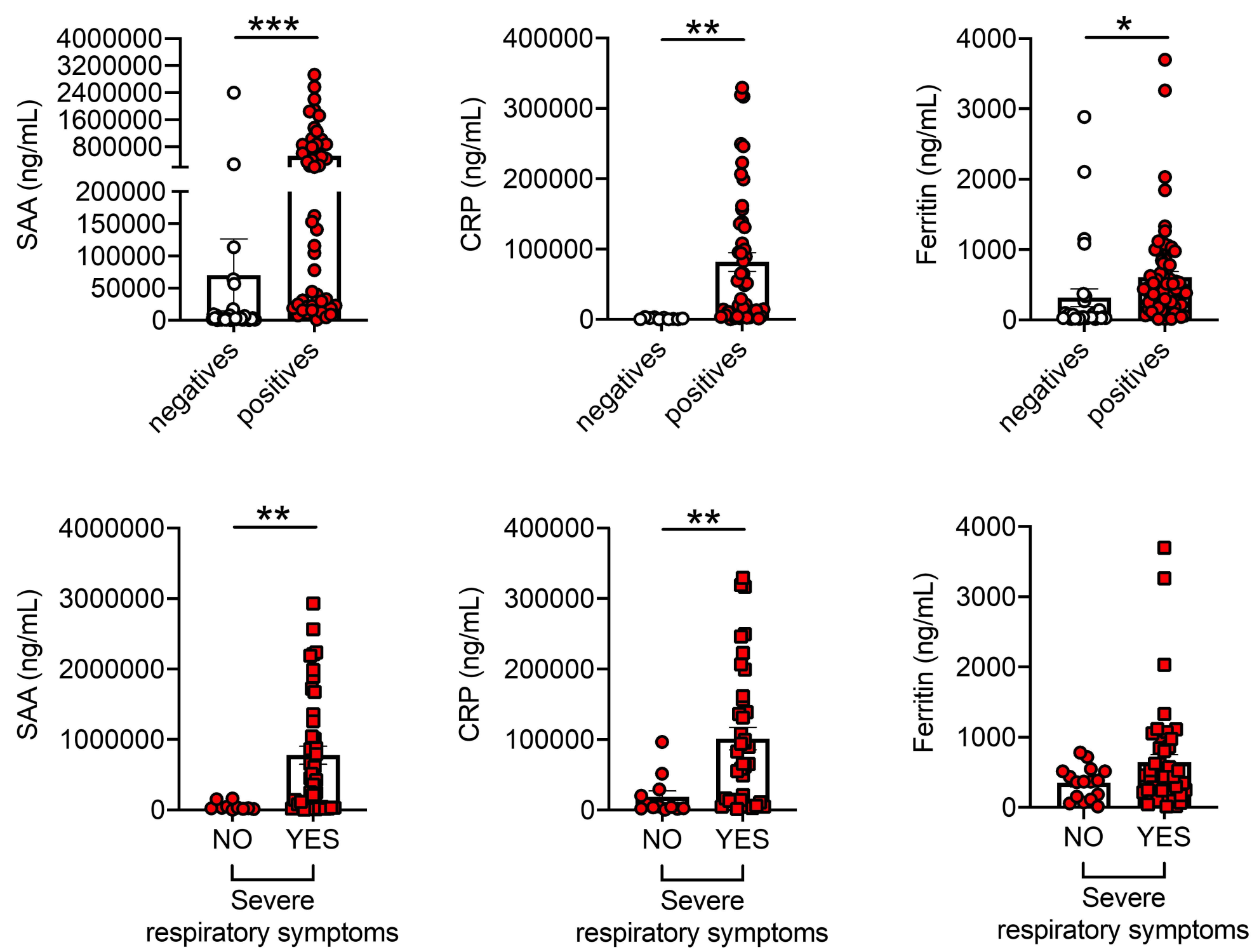

Fig. 2 

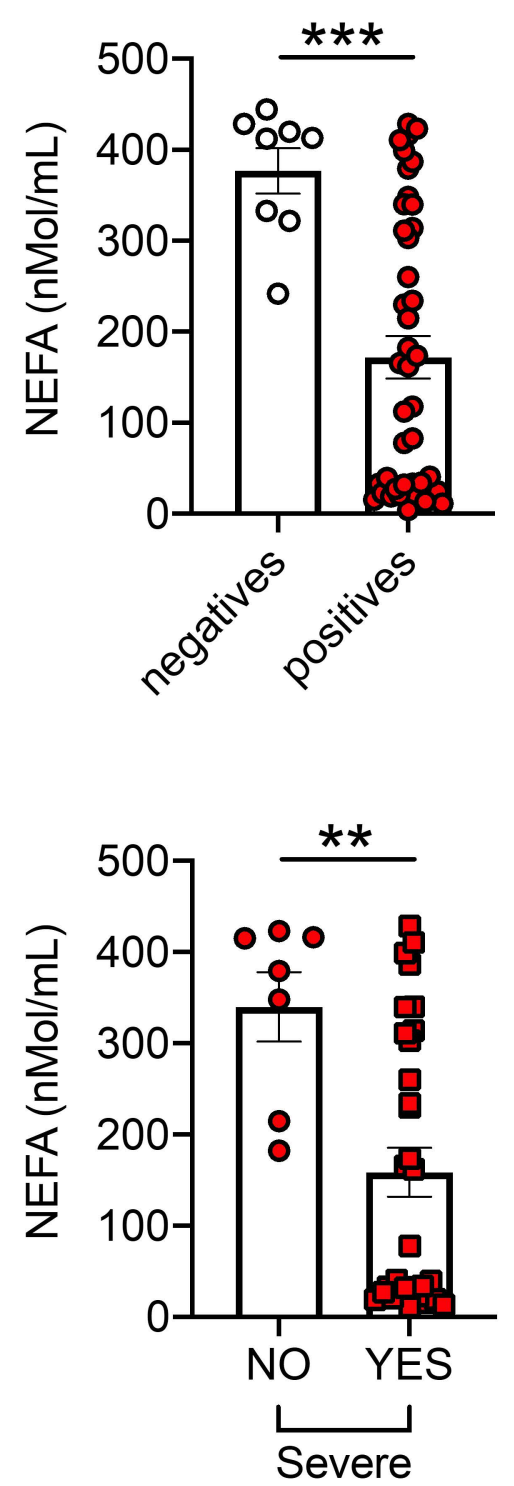

respiratory symptoms

Fig. 3 

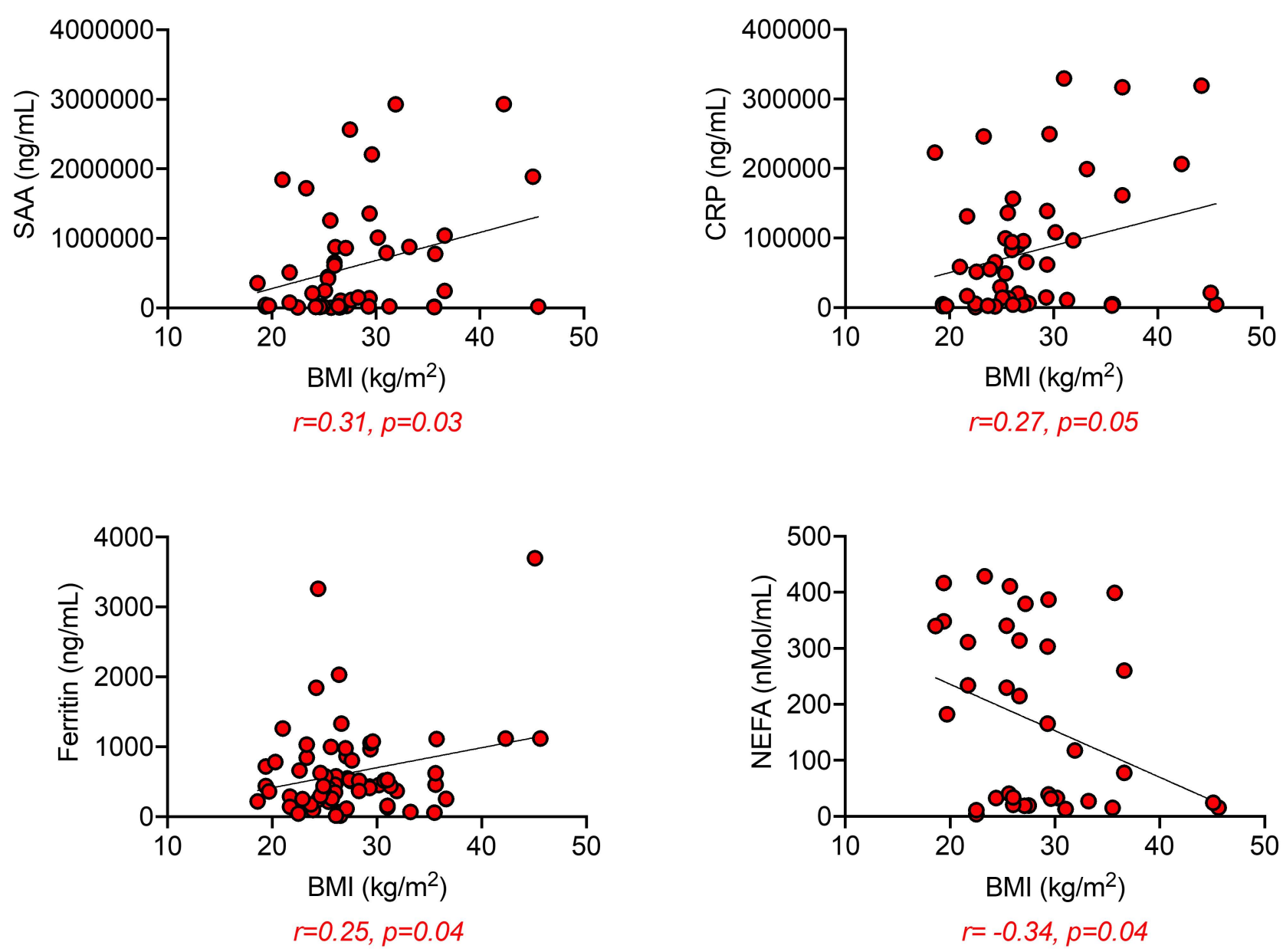

Fig. 4 

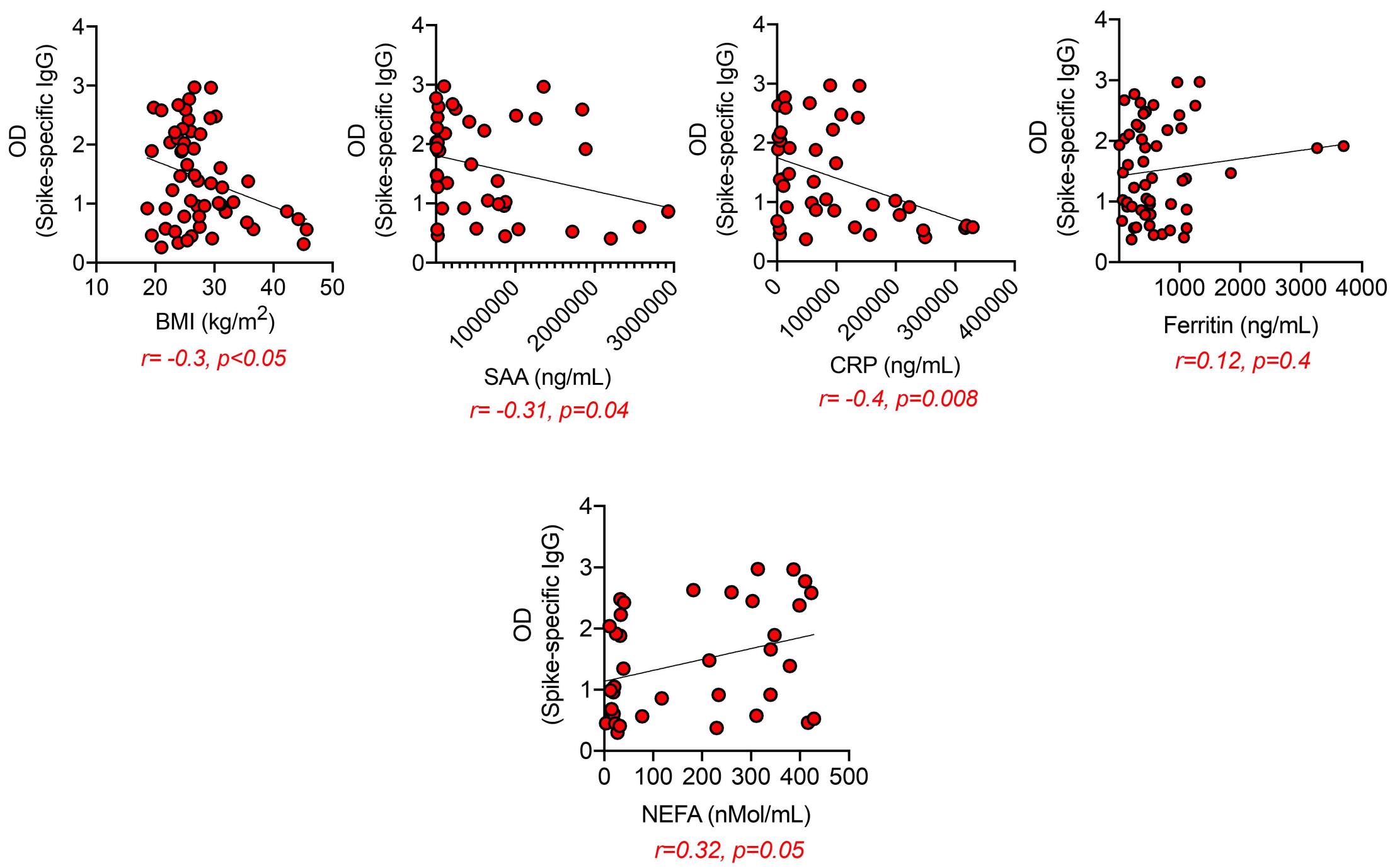

Fig. 5 